\title{
THE SYMBOLIC POWER OF SLEEPING WITHOUT MATTRESS PRACTICE IN KASURAN VILLAGE OF YOGYAKARTA
}

\author{
Saifuddin Zuhri Qudsy \\ UIN Sunan Kalijaga Yogyakarta \\ Email: saifuddinzuhri@yahoo.com \\ Irwan Abdullah \\ Universitas Gdjah Mada Yogyakarta \\ Email: irwanabdullah6@gmail.com \\ Zuly Qodir \\ Universitas Muhammadiyah Yogyakarta \\ Email: zuly_qodir@yahoo.com
}

\begin{abstract}
The work aims at exploring the practice of symbolic power of sleeping without kapok (matress) in a hamlet of Kasuran. It explores the process of reproduction of symbolic power and how it becomes a ritual practice preserved by the people of Kasuran. For many Kasuran people, Sunan Kalijaga saying is final. They understand and believe in his textual meaning by practising sleeping without matress ritual. The study finds that the reproduction of meaning of sleeping without mattress happens in the hands of agents that actively promote the myth about the saying of Sunan Kalijogo. They include Wartilah as the head of the hamlet (believing and promoting Sunan Kalijaga statement), Suharso as a pious man from Hindu tradition, secretary of the forum of harmony among religious blievers (believing that this myth is supposed to happen far before Sunan Kalijaga Era), Juremi and Suwardi, the takmir (board management of mosque) that represent religious mass organization of Muhammadiyah and Nahdlatul Ulama (NU). Although the agents have different points of view in understanding the phenomenon, they actually maintain and preserve this kind of symbolic power to gain symbolic capital. This work also finds that the dynamic process of engineering and modification of living without mattress becoming living with spon mattress/springbed has been the results of the new interpretation by the people in the village. The latest is associated with spiritual, social and political engineering aspects of the practice.
\end{abstract}

Keywords: sleeping, without, mattres, practice, symbolic, power, Kasuruan. 


\section{INTRODUCTION}

Kasuran is a small village, which has once become a place of killing of Dutch-Javanese troops by Diponegoro's troops in July 28, 1826. According to Louw and De Klerck's reports in 1894-1909, II: 497 as quoted by Peter Carey (2008:123) after an ambush in Kasuran, Sleman in July 28 1826, leaving seventeen people alive out of fifty members of a Dutch-Javanese platoon were killed. Diponegoro described the event and told how he rode a horse through (the battlefield) and was so conscience-stricken over those who had been killed and gotten injured. It was so tragic event that Diponegoro chose to close his eyes when facing the fact. Dusun Kasuran Kulon (or western Kasuran), a village located in Margodadi area, and Dusun Kasuran Wetan (or eastern Kasuran), located in the area of Margomulyo in Seyegan subdistrict, are two villages in Sleman District of Yogyakarta. This village, reported in many mass media, is regarded as one of the most unique villages in the world. Of around 828 inhabitants of Kasuran Kulon, as is claimed by Wartilah, $90 \%$ of them are sleeping without mattress, by using mats in place of it (DPPM UII, 2010). The above claim is also made by Wartilah and Noor Sidiq, the Headwoman/man of Kasuran Kulon and Wetan. This work intend focus on how Kasuran's citizens have produced and reproduced the practice of sleeping without matress and maintained it up to now.

As a consequence of various folklores passed down from generation to generation, Kasuran residents choose not to use kapok-mattress as their sleeping pads. However, when the oral tradition is examined, the above passage on the absence and prohibition of sleeping on mattress comes from a passed-down story saying that one day Sunan Kalijaga, at the time of the rule of Demak, dropped in the area of Grogol located not far from the Kasuran village. When the Dhuhr times came, he wished to perform the prayer and searched for water to take an ablution. However, he didn't find any water in the surroundings. Finally Sunan Kalijaga sticked his staff into the ground and the water came out of it which later known as Tuksibeduk. After performing the prayer, he felt tired and went to Kasuran village. In this village he asked the headman/woman, Kyai and Nyai Kasur, for kapok-mattress to sleep on. Having recuperated, he advised Kyai and Nyai Kasur that their villagers should not be negligent, even more to sleep on kapok-mattress. In times of the story, mattress is one of many symbols of luxury, material abundance, and idleness. It is one of many indications of the possession of economic capital at the time, meaning that if one has a mattress, it means that he lives in abundance. It is obvious from this fact that Sunan's advice "My descendants should not sleep on mattresses. They may do it if their spiritual power equals or surpasses mine" is interpreted literally, and not catch the true spirit and meaning of the 
message that, to some, discourages sluggishness.

Sunan Kalijaga's words, being passed down from generation to generation, have a serious implication. Non-mattress sleeping as a practice is a social phenomenon related to the structure of a society. It is why the non-mattress sleeping can be seen in its relation to social, cultural, and religious structure of Kasuran people. The study pertains to three important elements including the historical genealogy of non-mattress sleeping emergenve since its beginning as a mythological practice and the practice of non-mattress sleeping itself as seen a habituation. This work is based on qualitative reseacrh, which in some respects is one of the most natural and challenging methods of qualitative data collection. It connects the researcher with the most basic human experience, by engaging deeply in order to reveal how and why human behavior happens as it is in certain contexts (Spradley, 1980: 23).

\section{THE PRACTICE OF SLEEPING WITHOUT MATTRESS}

As is common to Indonesian folklores in general, no one knows for sure who was the first one who told the taboo or prohibition of sleeping on a kapokmattress in village Kasuran. There is also no one who is capable of confirming the beginning of the story of sleeping without kapok-mattress itself, either empirically or genealogically. The story flows spontaneously from generation to generation orally. It reminds us of an oral tradition being related quite often to folklore. Folklore also pertains to a tradition within certain segments of a society or a community. Its spread and endowment are done through mouths or orally (Dananjaya, 1986:5). It lives and exists as it is and spontaneously in the society, being accepted and lived by without much critical evaluations against it. Kasuran people, either Kulon or Wetan, lives it through with a complete nrima (fully accept it) attitude. This uncritical acceptance of the practice is what is called bodily hexis by Bourdieu (Bourdieu: 1977:93-94). The practice is hexis because it is believed, practised, and becomes a permanent disposition that occurs continually until it finaly becomes a kind of feeling or thought taken for granted. This mythological practice involves a "societal body" which is called a site of incorporated story by Bourdieu. That is, upon their body, a body that continually practise the attitude, way, or form of belief of sleeping without mattress that the story of village Kasuran is formed. As a result, in Kasuran, the mattress becomes a sacred object and thus forbidden to use by its inhabitants. Borrowing Durkheim's words, kapok-mattress becomes a sanctified items, i.e. items protected and singled out through a prohibition or taboo. (1995: 38).

Sleeping without mattress tradition in Dusun Kasuran comes from several 
different sources including from a religious saying by Sunan Kalijaga. Sunan Kalijaga's stopover in Kasuran and then his taking a rest by asking villagers to provide him with a mattress to sleep on, it is from here that the story is misrecognized into 'never ever sleep on kapok-mattress'. This version of Sunan Kalijaga is maintained by the village authority of one of whose pioneering members is Wartilah as a headwoman, and subsequently followed by many who regard her as an influential and esteemed figure. This is coupled by her active involvement in many activities, mainly pertaining to farmings. Another source is from Hinduism. The development of Hinduism in Kasuran is inseparable from the role of Pura Srigading, located in Kasuran Kulon, plays. According to Hindus' authorities, this practice of sleeping without mattress has existed far earlier than the coming of Islam. To avoid an open conflict with Islamic authorities' version, Suharso, an adherent and senior figure of Hinduism, a native of Kasuran Kulon, states that he doesn't affirm nor negate Islamic version of the story (myth or practice). However, he asserts that the practice has indeed existed far earlier than the coming of Islam. He asserts that it took place at the time of Majapahit rule.

The tradition also comes from Prince Diponegoro's men. Diponegoro War, also known as Java War, does indeed drains the energy of Diponegoro's troops as well as the Dutch. A defeat has forced some of Diponegoro's men to hide and launch a guerrilla war. One of their hiding places is Dusun Kasuran. The sufferings they undergo along with their families in their hiding place make them to swear not to live luxuriously and comfortably before the war ends. One remainder of such oaths up to now is the taboo of 'sleeping on mattress'. Mattress was, at the time, a symbol of luxury and idleness, hence they avoided it. An active agent who promotes this version of the story is Noor Siddiq who is a headman of dusun Kasuran Wetan. These three sources of the story have been actively accumulating the taboo of 'sleeping without mattress' in Dusun Kasuran and have been reproducing it continuously, especially done by the predecessors of dusun Kasuran up to the present generation. It is then becoming a practice and a habitus passed down and reproduced from generation to generation.

\section{THE SLEEPING WITHOUT MATTRESS PRACTICE AS A SOCIAL RECOGNITION CONTESTATION}

Sleeping on mattress prohibition, as far as understood as a myth, is in fact representative of people structure of thinking. Levi Strauss (as quoted by Morford \& Lenardon, 1999: 9) states that a myth is not merely of an illusion, but more of an internal structure representative of the state of the people 
who believe the myth in question, as previously explained by the author. Strauss sees a myth as a mode of communication, like that of language or music. There is no right or wrong for a myth because a myth, like society, is a living organism whose whole parts contribute to its existence. The life of a society and its or their structure of thinking seems to be the same as what the author infers from their internal structure, that is, live honestly, full of sincerity, and simple. However, unlike Strauss, Bourdieu tries to bring myths into a sociological (political) arena, in which there is an agent (individual) and a structure (social) who control why and how the myth should be treated. The practice of sleeping without mattress, for instance, shows a correlation between language and reality, which again a subject to be discussed in this paper. To Bourdieu, language doesn't merely possess a generative ability to make an unlimited number of sentences, but also an originative power to create what it says (Bourdieu 1995a: 37-38). Bourdieu asserts that which possess symbolic powers are not merely certain utterances supported by institutions, but he goes further that, to some degree and with varying effects, all utterances are performative. The prevailing practice and belief of sleeping without mattress takes on life and continues from generation to generation. It is accepted and narrated continuously to the next generation. During the last few years, it has become a trending topic either on television or virtual media.

It is through a language manifested in a story, which subsequently forms an opinion and later on makes up a social reality of a society, that the belief of sleeping without mattress is born. So, it might be said that language possesses a strong power to be able to create a new reality in a society, which automatically gives birth to (language) new vocabularies about something not found previously. Even after that, there occurs various forms either in the form of a resistance or of a modification of the practice, which, again in Bourdieuan terms, is a structuring structure and, at the same time, a structured structure (Bourdieu, 1984:170). So powerful an influence of the language upon reality and, later, so strong a generative power of reality over new vocabularies that, according to Sobur, they could move the world with merely speaking up utterances through the words in question. It is through the meaning of the words that human may run and direct his life meaningfully, either in a positive or a negative way. A language is even like a boomerang to human life as it could destroy the established order of reality (becoming a tyrannical language) (Alex Sobur, 2001: 16).

If the prohibition is understood as a myth, then, according to Bourdieu, it has to be put in its relation to culture, stratification, and power. In it, there is a struggle for social recognition. In this strruggle for social recognition, 
resources, processes, and cultural institutions place individuals and societal groups into a hierarchy of dominance. Regardless of whether it is a taste, clothing style, or eating habit or food according to religion, science, and philosophy-including the language itself-it is always surrounded by certain interests that, not rarely, create social stratification. Sunan Kalijaga's dawuh can be interpreted as a myth, as far as it discloses the structure of thinking of Kasuran people. However, there is a social contestation upon the meaning of mattress itself. Like a myth, it occurs as a kind of discourse, and every discourse-Foucault says-contains a power within. It is exactly on this point that the contestation doesn't merely work in the level of meaning, but also of praxis in a symbolic productive system. A pedukuhan (a village or subvillage) as an institution places the Headman, Wartilah, as an important agent in distributing the discourse.

Wartilah, although not a native of Kasuran, holds a central position from where the distribution of prohibition, myth, or taboo of sleeping on mattress is taking place. As mentioned in previous chapters, a discussion about the prohibition of sleeping on mattress always includes Wartilah as its main sourceperson or informant. One interesting fact is that how the discourse of hers (Wartilah) unconsciously puts aside other marginal perspectives, such as those of Noor Siddiq, Suharso, Suwardi, and Juremi, who have their own versions of the story and viewpoint. In marketing calculations, whether or not a product or a service is marketable is not only determined by how good is the quality of the myth (which is of course influenced by the 'magical' factor of Sunan Kalijaga), but also by how much and intensive is the distribution performed by Wartilah as the main supplier of the myth in question. Pedukuhan institution enables Wartilah to force the myth to be appropriated by Kasuran people. What is meant by 'appropriation' here is to make something, which is in fact alien, into our own possession or, borrowing Paul Ricouer, into Aneignung (Ricoeur, 1981: 185).

Pedukuhan institution is in fact the most powerful institution in terms of administration. Moreover, it is to be admitted that Wartilah is indeed a kind of amiable and friendly woman who possesses such various skills as pioneering organic farming activities, e.g. organic rice, and even popularizing blackrice farming in village Kasuran. She has been frequented and consulted by many farming groups or researchers. Lecturers of farming and agriculture have even invited her to explain farming practices to students. In addition to pedukuhan, other institutions such as NU, Muhammadiyah, FKUB, Pura Sri Gading, and principals of other communities have been struggling for positions to ensure the prevalence and equality of 'myth distribution'. In a 
larger scale, there is indeed a concerted effort to cooperate and fight for a joint cause: prohibition of sleeping on a mattress. However, according to Bourdieu, in the last analysis each institution turns out to be pursuing their own interest. This can be seen from the discourse they are trying to establish. It is clear in previous discussion about how Wartilah tends to base her version on Sunan Kalijaga's dawuh. Whether aware or not, she is making up a myth through a mythological historicity of the much revered Sunan Kalijaga among Muslims. Equipped with Muslim's support in Kasuran, Kasuran myth of Sunan Kalijaga version receives a bigger social recognition from the public than, for example, a Hindu version of the myth.

This huge support from a much bigger populace becomes a potential market for the distribution of Islamic version of the myth, and it means that Wartilah, as a headman, is categorized as "secure". The case is completely different, for example, from the myth Suharso, as a vice-head of FKUB and a Hindu adherent, tries to propagate. While history reveals that the coming of Hinduism took place hundreds or even thousands of years prior to Islam, its potential market is limited. Hindu's appropriation of the myth is far smaller than Muslim's. Meanwhile, another group such as the Headman of Kasuran Wetan, Noor Siddiq, seems to be less supported by the public, especially from among the youth who regard it as old-fashioned because 'sleeping without mattress' can be interpreted as 'sleeping on springbed' and, thus, the myth be sidelined. In another way, Noor Siddiq seems not to use the myth of Sunan Kalijaga as his story justification. He is more inclined to the version of Prince Diponegoro as it is closer in terms of time and more reasonable. The struggle for social recognition between Wartilah and Suharso is indeed obvious from their statements. For instance, when Suharso says that sleeping without mattress existed far more earlier than the coming of Islam, Wartilah counters it indirectly with her own version of the story based on Sunan Kalijaga. On this point, although they apparently work together to distribute the myth, they in fact struggle for discursive positions for their own prestige among Kasuran people concerning which version is the correct.

\section{SLEEPING WITHOUT MATRESS PRACTICE AND INTERSUBJEC- TIVE-NEGOTIATION}

In (political) sociology, Bourdieu may qualify as a hardliner in opposing a demarcation between the two notions (subjectivist and objectivist) while proposing a theoretical betterment through a "practical theory". This theory highlights virtuosic interaction inter-individuals in a habitus construction in certain cultural arena/field. Through a notion of habitus, Bourdieu enables us 
to see a relation of body-society from a collectivist base (an approach generally ascribed to Durkheim) or bodied-individuals (an approach usually attributed to Weber) (Mellor \& Shilling, 2013:349). Bourdieu's thesis about field of struggle, for example, facilitates a continuous dialectic between subjectivism (agent) and objectivism (structure) in Dusun Kasuran, involving the agency of certain figures (such as, Wartilah, Noor Siddiq, and so on) influenced by the internal structure of symbolic production of sleeping without mattress. The issue of, after securing its theoretical ontology, making habitus as a base is that Bourdieu seems to be entrapping himself in a biased predilection: more of objectivist than of subjectivist. When he asserts "think with a thinker against that thinker" (Bourdieu, 1990b: 49), this assertion of his will reveal how Bourdieuan way is employed to criticize-back its notion of "habitus" in the context of sleeping without mattress in Dusun Kasuran. To classify, there are at least two perspectives to criticize Bourdieu. First, as above explained, those focusing on the notion of habitus as they are considered to categorize Bourdieu as an objectivist thinker, something Bourdieu has rejected himself at the outset. Second, those viewing Bourdieu too engrossed in explaining his "practical theory" in such a way that he neglects the implication of structureagency dualism which has been his main undertaking from the start.

In "Bourdieu and the Logic of Practice", Evens (1999) criticizes Bourdieu's objectivism which he considers too sophisticated. To Evens, Bourdieu is a materialist who fails to see the intersubjective aspect of inter-individual relations. Bourdieu sees the practice of a ritual as a site of power and Evens perceives it as an issue of ethics instead. To Evens, intersubjectivity indeed does not assume a philanthropic action, for instance a virtuous gift, but it can explain why one needs to give something to another, not for his/her admittance in a social hierarchy, but because she/he-as a subject-is inseparable from his/ her relation to other subjects around him/her. This intersubjectivity relation is not always based on certain social structures, which determine inter-class division, but because he/she has existed in a social circumstance primordially, one in which the subjects interact one another. In Kasuran people, for example, giving something to someone is not always based on or motivated by a class-consciousness (proletariat and bourgeoisie), but also on a cooperative social consciousness (interclass cooperation).

The Bourdieuan power-relation does works on giving acknowledgment and/or social appreciation to Wartilah as a headwoman, but it is powerless in the context of visiting sickly relatives. Is this visitation, even if it is done voluntarily and in a virtuous manner (a term frequently employed by Bourdieu), always power-based? Such practices as these are overlooked by 
Bourdieu through his habitus. And this is more noticeable when giving and visitation are done differently by different individuals. Does a visit to Wartilah and a gift to her in her role as a neighbour, for example, have to be understood as a power exercise? Can such a practice be regarded as a habitus, even if it is practised differently among different individuals? If a habitus is understood as a continuous reproduction of a practice, stable and constant in nature, it means that the practice of visitation and giving-even if apportioned to such a cultural specialist as Wartilah-makes the habitus no longer relevant. Many villagers have come to Wartilah with gifts, and this is common, even though they subsequently discussed things pertaining to farming, organic rice, and village issues.

Bourdieu also criticizes those anthropologists who explain a social reality based on a "cultural map" they construct themselves. To Bourdieu, a society does not act according to certain rules, but they have been engaged from the start in their interaction with the circumstances without their being aware. I need to touch on Heidegger's concept (1999) about "factity", which is similar to Bourdieuan notion of "sense of game". To Heidegger, this factity occurs when a man/woman is not aware of why he/she is in the world, and why she/ he is amidst the other beings, among material objects. They are frequently not able to explain why they need to go to school, to go to work from 07:00 am to 05:00 pm, and do other daily chores without posing further questions. They just run the day without reserve, and, as such, they feel being in the world. The notion of similarity of Bourdieu to that of Heidegger lies on the fact that a structure forms and is formed by an unconscious agent, one who no longer needs to learn about prior rules, who goes with the flow without reason. A comparable example would be a professional football player, who no longer needs to learn about function of lines in soccer field, offside line, sideline, rule of fairplay, penalty, yellow and red cards, and so on. They are being (as) a player without basic knowledge about prior principles. To make a comparison to three schemes of Gidden's awareness (2010:10; Priyono, 2002:28), they have possessed-what is called as-practical consciousness, a kind of intimate comprehension about an object and a situation they run daily, without further questions.

In the context of Kasuran people, Bourdieu will assert that sleeping without mattress is performed by the people because they not only realize the rule of Sunan Kalijaga, of Prince Diponegoro or that of Hindu's version, but they also perform it unconsciously. They sleep without mattress because such is the sense of game (1990:63) which directs them, such is the practical consciousness that guides them, a sort of awareness they are unable to explain why and 
wherefrom. In Bourdieuan terms, that consciousness is already embedded in each individual, which means that this consciousness is what determines how the structure works to influence the agent. Being only equipped with a practical consciousness, a kind of 'unconscious consciousness' (misrecognition), it is this existence of thing, material, and object (i.e. 'sleeping without mattress as material structure') that influences the performativity of the agents. This is what makes the action of the agents social, because they are tied by one single material structure: 'sleeping without mattress'.

In this regard, there are three points overlooked by Bourdieu. First, Kasuran people do not have a complete practical awareness in performing sleeping without mattress. That is, there are some who perform it on their own initiative; they have their own reasons why the tradition should be followed. As explained previously, some sleep without mattress for being told to do so by parents, for fear of mythical curse, for being influenced by Wartilah et al., and even just "go with the flow". Now, these reasons do show that it is not merely structure that influences the agent's performivity, but also inter-agents intersubjectivity that determines the practice. Second, this is also what makes Bourdieu, in author's view, lagged behind compared to Giddens, as the latter promotes-besides practical consciousness - what he calls discursive consciousness, i.e., an active ability to verbalize surrounding social circumstances. Unlike Bourdieu who places an agent always in a state of factist and ideological unconsciousness, Giddens mentions the possibility of a discursive awareness in the agent to realize what he is doing as a social actor. A football player, even though he gets used to-and becomes unconscious of - rules, does possesses a discursive awareness of what he is doing in a soccer field. So is Kasuran people, even if they are accustomed to sleeping without mattress, it doesn't mean that they are not capable of explaining the reason behind the practice. Some even realize that they have been being 'indoctrinated' by an ancestral tradition passed down for hundreds of years.

Third, as a consequence of the above discursive consciousness, Kasuran people is eventually not genuinely 'social' (in the sense that they are completely influenced by material structure of 'sleeping without mattress'), as they always negotiate one another to determine their attitude towards the tradition. As a result, as will be explained later, this negotiation enables an individual to manipulate common understanding about the practice of sleeping without mattress (King, 2000: 421). Bourdieu's habitus indeed implies a static and anachronic social structure (the reason: it is not other individuals who influence an individual preference for a practice, but the structure that is fixed and stable) that it doesn't work in intersubjective level (in which the individual 
defines his/her preference, not because of the surrounding habitus, but of others' influence). In the first section of Outline of A Theory of Practice (1977), Bourdieu indeed succeeds in merging objectivism and subjectivism into a notion of "individual as a virtuous agent", one whose action/practice always influenced by surrounding other agents (intersubjectivity-social structure as dynamic structure, not static-etc.). However, in his later work, The Logic of Practice (1990a), Bourdieu admits openly instead his more objectivist tendency rather than subjectivist, mainly when he appeals us to return to 'practice" as the site of dialectice of "opus operatum" and "modus operandi"; of objectified products and incorporated products of historical practice; of structure and habitus (Bourdieu, 1990a: 52).

\section{CHANGE AS AN UTOPIA: HYSTERIC EFFECT IN DUSUN KASURAN}

Bourdieu (1996: 219) once refers to hysteric effect which seems to employ to legitimize social change on his notion of habitus. Hysteric effect is understood as a situation in which habitus lags behind the objective material condition which occurs at the time (Bourdieu, 1984: 142). The example Bourdieu offers is the division of an academic institution between, for example, humanities and science. To Bourdieu, scheme of education must change because material conditions change. If an education was monogeneralist in the past, now the education starts to implement specialisation. Educational specialisation is a form of novel habitus as a response to material conditions of old-fashioned and altered monogeneralist education. In this work, sleeping on sponge-mattress is a hysteric effect of sleeping without mattress which is considered as already altered. As the material objective condition is altered (previous: sleeping without mattress whatsoever), the habitus is also altered (now: sleeping on sponge-mattress). Meanwhile, in Kasuran Kulon, as there is no alternation of objective material condition, the habitus remains the same until now (sleeping without mattress whatsoever).

Now, it is clearer that hysteric effect is only a utopian effect which doesn't respond to any kind of change, not merely that it attaches 'effect' on novel conditions and abandons old ones, but also that-inside-we dimly hear Bourdieu's voice so persistent from the start in claiming that habitus is the predeterminant structure over the agency. Thus, all must begin with objective material condition, not with agent intersubjectivity. As long as material condition doesn't change, as long as the change is only measured out of interagents interaction, the habitus will never occur. That is, so long as 'sleeping on sponge-mattress' is regarded as a result of inter-agents interaction-even if such is the case-it can not be considered as a habitus. 'Sleeping on sponge- 
mattress' can only be regarded as a habitus as far as material condition at the time positioned the sponge as a common sense in Kasuran. The problem is, how do we measure the alteration of material condition in a village, in which a whole area are using the sponge, while another still use matress? Can the existence of 'sponge' be considered as a parameter of material change in a community some of which still use matress?

Hysteric effect is also incompatible with Bourdieu's initial assumption of misrecognition. The rationale is, if hysteric effect is determined by material condition which requires the alteration of the practice of agents, doesn't it, by definition, also require the awareness of agents to make the change itself? It is not the widespread use of 'sponge' that influences the practice modification in Kasuran Wetan, but more of the 'active consciousness' of the people there in responding to the sponge itself, an awareness which is absent from among Kasuran Kulon people. The use of 'sponge' is not relatively so influential to Kasuran Kulon people that its use as a material objective alteration is problematic. That is, the modification of practice is more influenced by the consciousness of Kasuran people, and this consciousness is, of course, not practical consciousness - taken for granted without further questionings (or in Bourdieuan terms, misrecognition)—but discursive consciousness.

Rancière (1986: 28; Pelletier, 2008: 4) formulates the logic of Bourdieuan argumentation of education in two forms. First, working-class is marginalized from the universities because they do not understand the rational reasons behind their marginalisation. Second, the unconsciousness of those rational reasons is a structural effect produced by the university system itself. To Ranciere, instead of advocatingan educational reformation, Bourdieu maintains status quo instead. This criticism of Ranciere is relevant dan comparable to the context of Kasuran people. First, who is the working class? They are the laypeople, who do not understand why they are regarded as common folks in social-class division, in which Wartilah et al. are the elite. Second, when they do not understand the matter, they are in fact being enslaved by the structure they themselves and are not aware of from the very beginning. Hence, it is clear how objectivist is Bourdieu in placing the structure as the controller of status quo with misrecognition as the potent ideological tool to prod and move the working class voluntarily. This analogy is even clearer when Wartilah et al. are positioned as a teacher-a reference of the practice of sleeping without mattress in Kasuran-who have discursive consciousness, but abandon the repressive structure in question instead. Meanwhile, laypeople act as pupils, possessing practical consciousness (misrecognition), but who don't realize the structure alienating them. 
We can learn from Ranciere about how emancipation that should be born of proletariat, of the laypeople in question. Bourdieu's slippage, as a materiaist, lies on the way he regards everything that should always begin with injustice, in such a way that emancipation is only generated as a temporal issue. Emancipation is never obtained factually, as we always step and depend on the said injustice, from assuming, affirming, to providing it with epistemological basis to verify its existence. So long as we are convinced that Kasuran people are divided into social-classes, that they are not aware of this class division, we will then only see a cultural status quo. For this, it is important to position laypeople as 'civilized' masses, ones who have 'discursive consciousness', who rebel against the power of culture, so that-what we envisions as-social change and emancipation are possible to grab and realize. In fact, this point of view can be used to see the phenomenon of 'sleeping without mattress' in Dusun Kasuran, as long as the laypeople is taken into account within. In previous section, the author has discussed about how Bourdieuan workings covertly only affirms the position of cultural specialists, such as Wartilah and Noor Siddiq, by providing them with more rooms to talk, especially after the introduction of journalistic field. There is almost none of laypeople's views or opinions about the tradition. If there is any, it is supportive, because such is the case - to Bourdieu - that they are a group of people who misrecognize the structure curbing them.

Actually, the fact of the matter is quite different or, to be more accurate, not as previously supposed. During the interview, the author finds that many of their arguments-to some degree-are different from those of cultural/religious specialists. A local, who is a lay person in his daily routine, for example, is convinced that the tradition is brought into Kasuran by an outsider or immigrant, and has no connection at all to Sunan Kalijaga. Some locals even suspect the Wartilah's involvement, who is not a native of Dusun Kasuran, in propagandizing 'sleeping without mattress' again. In fact, before her coming into Kasuran, there were many locals who had been using mattresses and generating no mythical 'curses'. Others are convinced that the tradition is maintained just for commertial purposes: promoting Dusun Kasuran to the larger public, in order to get more financial support from the local government. This is evidenced by a demand for more village fund whenever an individual or an institution wish to do a research in Dusun Kasuran. Even to some degree, the relic of Sunan Kalijaga, Tuk Si Beduk site, has now become a place for annual cultural event, with financial support from Sleman local government, which promotes Desa Margodadi as one of the many tourist destinations not merely recreative, but also, and especially, spiritual. 


\section{CONCLUSION}

The issue of sleeping without mattress is more of spiritual in nature. The ways people express their faith of sleeping without mattress tradition are heterogenous. Spiritual capital can be a stronger exchange rate than religious capital, and the people may capitalize on spiritual power through a symbolic capital they have accumulated from other arenas/fields. Emphasizing spiritual capital over religious capital enables the spiritual capital to be shared by all people, regardless of their positions in certain religious infrastructure. In the context of sleeping without mattress and symnolic power, Kasuran people are divided into several hierarchical categories including the cultural elite, the organisational elite who hold structural positions but oppose the practice and semi-peripheral group who are fanatical but hold no position, such as NU members in Kasuran, and the peripheral or marginal group.

Sleeping without mattress is performed by the people unconsciously. They sleep without mattress because the consciousness is already embedded in each individual. Some sleep without mattress for being told to do so by parents, for fear of mythical curse, for being influenced by Wartilah et al., and even just "go with the flow". These reasons do show that it is not merely structure that influences the agent's performivity, but also inter-agents intersubjectivity that determines the practice. The practice of sleeping without mattress is eventually understood as a material dialectic. Sleeping without mattress is considered as opus operatum as far as understood as a product of culture (tradition) long existed. However, it can also be defined as modus operandi as it implies a strategy (practice) adopted by individuals. Bourdieu does not give a space for 'agency', for intersubjectivity; all must begin with material basis. Sleeping without mattress as a cultural habitus is not produced by a continuous and dinamic dialectic between an agent and a structure, but by a dialectic between a practice and a structure. Finally, Kasuran people is not of a community based on inter-individuals interaction, but of a community based on a practice and a structure. The tradition of sleeping without mattress is not a result of individual negotiation but of a cultural product long existed and performed unconsciously up to now.

\section{BIBLIOGRAPHY}

Abdullah, I. (2006). Konstruksi dan Reproduksi Kebudayaan, Yogyakarta: Pustaka Pelajar.

Abdullah, I., Udasmoro, W. \& J. H. (2009). Dinamika masyarakat dan Kebu- 
dayaan Kontemporer, Yogyakarta: Pustaka Pelajar \& TICI.

Arac, J. (1986). Posmodernism and Politics, UK: Manchester University Press.

Becker, G. (1976) The Economic Approach To Human Behavior, Chicago: University of Chicago Press.

Bendixsen, S. (2013). The Religious Identity of Young Muslim Women in Berlin: An Ethnographic Study, Leiden: Brill

Bernard, H. R. (2006). Research Methods in Anthropology. Lanham, MD: Altamira Press.

Branson, J. \& Miller, D. (2005). "Pierre Bourdieu" dalam Peter Beilharz, Teori-teori Sosial, (terj. Sigit Jatmiko), Cet. 3, Yogyakarta: Pustaka Pelajar.

Bourdieu, P. (1962). The Algerians, US: Beacon Press.

, (1971). 'System of education and systems of thought, and intellectual field and creative project', in M.F.D. Young (Ed) Knowledge and Control: New Directions for the Sociology of Education, London: Collier Macmillan.

, (1977). Outline of A Theory of Practice, translated by Richard Nice, Cambridge, U.K.: Cambridge University Press. (1984). Distinction: A Social Critique of the Judgement of Taste, translated by Richard Nice, London: Routledge.

, (1986). "The Forms of Capital", terj. (translated by Richard Nice). In J.G. Richardson (Ed.), Handbook for Theory and Research for the Sociology of Education, New York: Greenwood Press.

, 1990). Homo Academicus, translated by Peter Collier, California: Stanford University Press.

, (1992). The Logic of Practice. translated by Richard Nice. Stanford: Stanford University Press

, (1990). The Field of Cultural Production: Essays on Art and Literature, edited by Randal Johnson, Cambridge: Polity Press.

(1993). Sociology in Question. translated by Richard Nice. London: Sage.

1994). In Other Words. translated by Matthew Adamson, Cambridge: Polity Press.

, (1995). Outline of A Theory of Practice. Translated by Richard Nice. Cambridge: Cambridge University Press. 
(1995a). Language and Symbolic Power. Translated by Gino Raymond \& Matthew Adamson, Cambridge: Polity Press.

, (1996). The State Nobility. Cambridge, U.K.: Polity Press.

, (1998). Acts of Resistance: Against the Tyranny of the Market. Translated by Richard Nice. New York: The New Press.

, (1998b). Practical Reason: On the Theory of Action. California: Stanford University Press.

, (2002) Jurnalisme di Televisi. Translated by Dadang Rusbiantoro. Yogyakarta: Yayasan Kalamakara \& Akindo.

Bourdieu, P. \& Wacquant, L. (1993). "From Ruling Class to Field of Power: An Interview with Pierre Bourdieu on La noblesse d'État". in Theory, Culture \& Society Vol. 10, hal. 19-44.

1999, “The Cunning of Imperialist Reason", dalam Theory, Culture, and Society Vol. 16(1), hal. 41-57.

Carey, P. (2008). The Power of Prophecy, Prince Dipanegara and the End of an Old Order in Java, 1785-1855. (II ed.). Leiden: KITLV Press.

Chojim, A. (2013). Mistik dan Makrifat Sunan Kalijaga, Jakarta: Serambi.

Danandjaja, J. (1984). Folklor Indonesia. Jakarta: Pustaka Grafitipers.

Degroot, V. M. Y. (2009). Candi Space and Landscape: A Study on the Distribution, Orientation and Spatial Organization of Central Javanese Temple Remains. Unpublished Disertasi. Leiden University.

DeWalt, K., \& DeWalt, B. (2011). Participant Observation: A Guide for Fieldorkers (2nd ed.). Lanham, MD: AltaMira.

Dianteill, E. (2003). Pierre Bourdieu and the Sociology of Religion: A Central and Peripheral Concern. Theory and Society, 32(5/6), 529-549. Retrieved from http://www.jstor.org/stable/3649650

Durkheim, E. (1995). The Elementary Forms of Religious Life, (trans. Karen E. Field), New York: The Free Press.

Evens, T. (1999). Bourdieu and the Logic of Practice: Is All Giving Indian-Giving or is "Generalized Materialism" Not Enough?, Sociological Theory, 17(1), 3-31. Retrieved from http://www.jstor.org/stable/201925

Faelasofa, D. (2013). Ajaran Sunan Geseng bagi Kehidupan Keagamaan Masyarakat. Komunitas: International Journal of Indonesian Society and Culture, 3(2). doi:https://doi.org/10.15294/komunitas.v3i2.2312

Fashri, F. (2014). Kuasa Simbolik Bourdieu, Yogyakarta: Jalasutra. 
Foucault, M. (1972). The Archaeology of Knowledge, London: Tavistock, , (1981). "The Order of Discourse", in Young, R. (edt) Untying the Text: a Postructuralis Reader, London: Routledge.

Gao, J. (2012). The Use of Media by Chinese Public Intellectuals. Journal for Communication and Culture 2, no. 2 (winter 2012)

Gaventa, J., 2003. Power after Lukes: a Review of the Literature, Brighton: Institute of Development Studies.

Gertz, C. (1968). Islam Observed. Chicago: The University of Chicago Press. , (1983). Santri, Priyayi, dan Abangan, (trans. Aswab Mahasin). Jakarta: Dunia Pustaka Jaya.

Giddens, A. (2010). Teori Strukturasi: Dasar-dasar pembentukan Struktur Sosial Masyarakat, (trans. Maufur \& Dariyatno). Yogyakarta: Pustaka Pelajar.

Hanks, W. F. (2005). Pierre Bourdieu and the Practices of Language. Annual Review of Anthropology, Vol. 34: 67-83.

Harker, R., Mahar, C. \& Wilkes, C. (editor), (2009). (Habitus x Modal) + Ranah= Praktik Pengantar Yang Paling Komprehensif Kepada Pemikiran Pierre Bourdieu. Yogyakarta: Jalasutra

Haryatmoko, (2003). Menyingkap Kepalsuan Budaya Penguasa. Majalah Basis edisi khusus Pierre Bourdieu No. 11-12, tahun ke 52. , (2010). Dominasi Penuh Muslihat: Akar Kekerasan dan Diskriminasi. Jakarta: Gramedia.

Heidegger, M. (1999). Ontology: The Hermeneutic of Facticity, Indiana: University of Indiana Press.

Hentschel, U., Smith, G., Draguns, J.G., Elsevier, W.E. (Eds), (2004). Defense Mechanisms: Theoretical, Research and Clinical Perspectives, Amsterdam: Elsevier.

Hereyanto, (2009). “Tradisi Keagamaan dan Kekuasaan Simbolik di kalangan Masyarakat Amuntai Kalimantan Selatan” Yogyakarta, Thesis, UGM.

Hidayat, A. R. (2006). "Bahasa dan Hegemoni Kekuasaan (Telaah atas Kekerasan Simbolik di dalam Media)" in KARSA, Vol. IX No. 1 April 2006.

Horkheimer, M., Adorno, T.W. (2002). Dialectic Enlightment: Philosophical Fragments, (trans. Gunzelin Schmid Noerr). California: Stanford University Press. 
Humas Setda Kab. Sleman, (2015). Buku kerja 2015. Penerbit Humas Setda Kab. Sleman.

Jenkins, R. (1992). Pierre Bourdieu, London: Routledge.

Jenkins, R. (2010). Pierre Bourdieu (trans.). Yogyakarta: Kreasi Wacana

Johnson, R. (2010). "Pengantar Pierre Bourdieu tentang Seni, Sastra, dan Budaya”. Arena Produksi Kultural, Sebuah Kajian Sosiologi Budaya. Traslated by Yudi Santosa. Yogyakarta: Jalasutra.

King, A. (2000). Thinking with Bourdieu against Bourdieu: A 'Practical' Critique of the Habitus. Sociological Theory, 18(3), 417-433. Retrieved from http://www.jstor.org/stable/223327

Koentjaraningrat, (1994). Kebudayaan Jawa, Jakarta: Balai Pustaka.

Mellor, P.A. \& Shilling, C. (2013). "Habitus Agama: Pengejawantahan Agama dan Teori Sosiologi," in Bryan S. Turner (Ed.), Sosiologi Agama, (trans. Dariyatno) Yogyakarta: Pustaka Pelajar.

Mills, C. (1956). The Power Elite, London: Oxford University Press.

Morford, M.P.O. \& Lenardon, R.J. (1999). Classical Mythology (6 ${ }^{\text {th }}$ edition), New York, Oxford University Press.

Navarro, Z. (2006). "In Search of Cultural Intepretation of Power". IDS Bulletin 37(6): 11-22.

Nurhajarini, D.R. (2012). Yogyakarta: Dari Hutan Beringin ke Ibukota Daerah Istimewa, Yogyakarta: Kemendikbud.

Pals, D.L. (1996). Seven Theories of Religion, New York: Oxford University Press,

Pelletier, C. (2009) Emancipation, equality and education : Rancière's critique of Bourdieu and the question of performativity. Discourse: Studies in the Cultural Politics of Education , 30 (2) pp. 137-150. Retrieved from http://discovery.ucl.ac.uk/10003196/

Piliang, Y.A. (2004). Posrealitas: Realitas Kebudayaan dalam Era Posmetafisi$k a$, Yogyakarta : Jalasutra , (2003). Hantu-Hantu Politik dan Matinya Sosial, Solo: Tiga Serangkai

Poespoprodjo, W. (1987). Interpretasi: Beberapa Catatan Pendekatan Filsafatinya, Bandung: Remadja Karya

Prasad, P. (2005). Crafting Qualitative Research: Working in the Postpositivist Traditions, Ney York, M.E. Sharpe. 
Priyono, B.H. (2002). Anthony Giddens: Suatu Pengantar, Jakarta: Kepustakaan Populer Gramedia.

Putro, Z. (2015). Ketahanan Toleransi Orang Jawa: Studi tentang Yogyakarta Kontemporer. MASYARAKAT: Jurnal Sosiologi, 15(2). Retrieved March 25, 2018, from http://journal.ui.ac.id/index.php/mjs/article/ view/4860

Qodir, Z. (2010). Muhammadiyah Studies: Reorientasi Gerakan Dan Pemikiran Abad Kedua, Yogyakarta: Kanisius

Rancière, J. (1984). "L'éthique de la sociologic”, Lempire du sociologue (13-36), Collectif Revoltes logiques. Paris: Éditions La Découverte.

Reid, A. (2011). Asia Tenggara dalam Kurun Niaga 1450-1680, terj. Mochtar Pabottinggi, Jakarta: YOI.

Rey, T. (2007). Bourdieu on Religion, Imposing Faith and Legitimacy, UK. Equinox Publishing.

Riceuor, P. (1981) Hermeneutics and the Human Sciences, Cambridge: Cambridge University Press.

Rusdiarti, S.R. (2003). Bahasa, Pertarungan Simbolik dan Kekuasaan. in Majalah Basis edisi khusus Pierre Bourdieu No. 11-12, tahun ke 52. Denzin, Norman K. \& Yvonna S. Lincoln, 2009. The Sage Handbook of Qualitative Research, (trans. Daryatno) Yogyakarta: Pustaka Pelajar

Scott, J.C. (1993). Perlawanan Kaum Tani, Jakarta: Yayasan Obor Indonesia

Seino, K. (1988). "Islamization of Java: Missiological Analysis" US: Fuller Theological Seminary, Thesis.

Spencer, B. \& Gillen, F.J. (1904). Northern Tribes in Australia, London: Macmillan.

Spradley, J. P. (1980). Participant Observation. New York, NY: Holt, Rinehart \& Winston

Subardi. (2009). Mbah Bregas: Menemukan Keteladanan Pada Masa Lalu, Yogyakarta: JalaSutera

Susen, Simon \& Turner, B.S (2013). The Legacy of Pierre Bourdieu, New York, Anthem Press.

Suwardi, (2010). Foklor Jawa, Jakarta: Penaku.

Sobur, A. (2001). Analisis Teks Media. Bandung, Rosda Karya.

Swartz, D. (1997). Culture and Power: The Sociology of Pierre Bourdieu, Chicago: Chicago University Press. 
Swedberg, R. \& Agevall, O. (2005). The Max Weber Dictionary: Key Words and Central Concepts, California: Stanford University Press.

Taqwa, R. (2009). Relasi Kuasa antara Media Televisi yang Dominatif-Hegemonik VS Audiens yang Aktif-Kritis : Suatu Perspektif Cultural Studies. WACANA INDONESIA Jurnal Mahasiswa dan Alumni Pascasarjana se-Indonesia , 1 (1). pp. 67-74. ISSN 1858-0358. Retrieved from http:// eprints.unsri.ac.id/3390/

Telaumbanua, S. (2012). "Pendekatan Pengkajian Folklore dan Mitos" hlm. 287, in www.isjd.pdii.lipi.go.id/admin/jurnal/2108282297.pdf, retrieved on 20 Desember 2012.

Thompson, J. B. (1984). Studies in the Theory of Ideology. Berkeley: University of California Press.

Torrance, J. (1995). Karl Marx’s Theory of Ideas, Cambridge: Cambridge University Press.

Turner, B.S. (Ed.). (2013). Sosiologi Agama, (trans.. Daryatno), Yogyakarta: Pustaka Pelajar.

Umar, H. (1984). Sunan Kalijaga. Kudus: Menara.

Verter, B. (2003). Spiritual capital: Theorizing religion with Bourdieu against Bourdieu. Sociological theory, 21(2), 150-174. Retrieved from https:// doi.org/10.1111/1467-9558.00182

Webb, J., Schirato, T. \& Danaher, G. (2002). Understanding Bourdieu, London: Sage Publication.

Weber, M. (1968). Economy and Society. Berkeley, CA: University of California Press. , (2006). Sosiologi, (trans. Noorkholis), Yogyakarta: Pustaka Pelajar.

Yuwono, S. H. (2014). Buku Panduan Riwayat Desa Kasuran dan Pura Sri Gading. Yogyakarta: Tp 